\title{
CASP9 Gene
}

National Cancer Institute

\section{Source}

National Cancer Institute. CASP9 Gene. NCI Thesaurus. Code C28424.

This gene plays a role in the initiation of the apoptotic cascade. 